\title{
POLITICAL CORRUPTION AND SCANDALS IN JAPAN
}





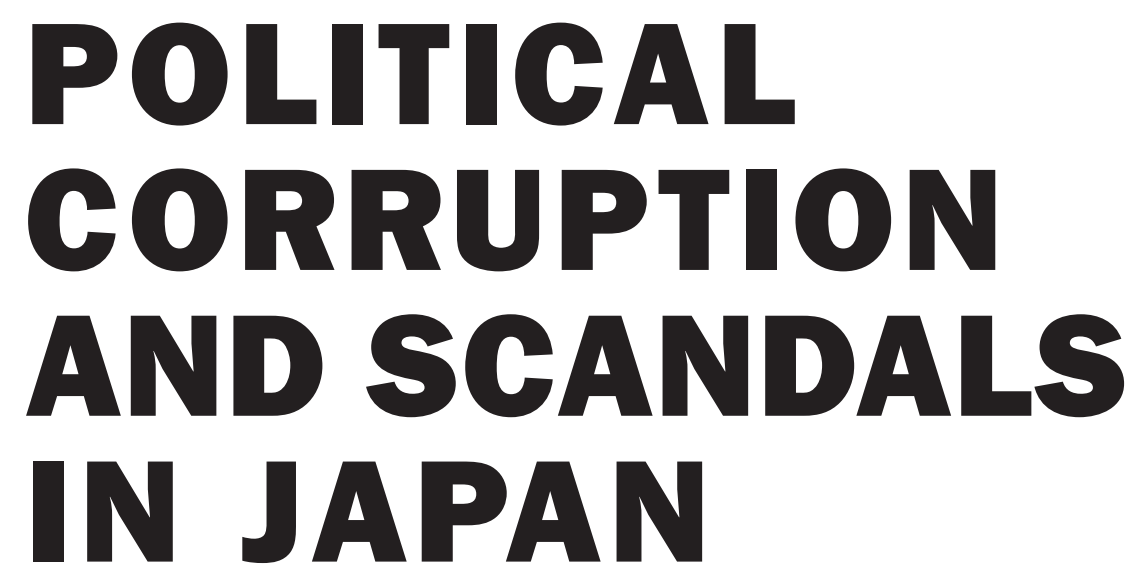

Matthew M. Carlson and Steven R. Reed 
Cornell University Press gratefully acknowledges receipt of a subvention from the Department of Political Science, University of Vermont, which aided in the publication of this book.

\section{Copyright (@ 2018 by Cornell University}

All rights reserved. Except for brief quotations in a review, this book, or parts thereof, must not be reproduced in any form without permission in writing from the publisher. For information, address Cornell University Press, Sage House, 512 East State Street, Ithaca, New York 14850.

First published 2018 by Cornell University Press

Printed in the United States of America

Library of Congress Cataloging-in-Publication Data

Names: Carlson, Matthew M., 1972- author. | Reed, Steven R., 1947- author. Title: Political corruption and scandals in Japan / Matthew M. Carlson and Steven R. Reed.

Description: Ithaca : Cornell University Press, 2018. | Includes bibliographical references and index.

Identifiers: LCCN 2017025014 (print) | LCCN 2017031399 (ebook) | ISBN 9781501715662 (epub/mobi) | ISBN 9781501715679 (pdf) | ISBN 9781501715655 (cloth : alk. paper)

Subjects: LCSH: Political corruption-Japan-History. | Scandals—JapanHistory. | Japan-Politics and government-1945-

Classification: LCC JQ1629.C6 (ebook) | LCC JQ1629.C6 C37 2018 (print) | DDC 364.1/3230952-dc23

LC record available at https://lccn.loc.gov/2017025014

Cornell University Press strives to use environmentally responsible suppliers and materials to the fullest extent possible in the publishing of its books. Such materials include vegetable-based, low-VOC inks and acid-free papers that are recycled, totally chlorine-free, or partly composed of nonwood fibers. For further information, visit our website at cornellpress.cornell.edu.

Cover: National Diet Building (Kokkaigijidou), Tokyo. Photograph by Tanaka Nobuaki. 